\title{
Deformation Behavior and Mechanical Properties of Ferrite-Bainite-Martensite (Triphase) Steel ${ }^{*}$
}

\author{
By Masatoshi SUDO** and Takafusa IWAI**
}

\begin{abstract}
Synopsis
The effect of microstructures on the mechanical properties of multi-phase steels has been studied. The amount and nature of low temperature transformation products of the steels are changed through heat treatment and controlled cooling after hot rolling. Ferrite plus bainite steel has superior stretch-flangeability and fatigue strength while it is inferior in strengthuniform elongation relationship to ferrite plus martensite ("dual-phase") steel.

Introduction of a small amount of martensite to ferrite plus bainite steel gives rise to a decrease in yield ratio and increase in work hardening rate. The microscopic examination shows that pearlite and martensite particles nucleate cracks easily and replacement of pearlite and martensite particles by more ductile bainite particles results in improved ductility. Stretchflangeability of triphase steel is also improved by decreasing martensite particle size. It is concluded that ferrite-bainite-martensite (triphase) steel may be preferred to ferrite-martensite steel in automobile applications.
\end{abstract}

\section{Introduction}

Development of high strength hot-rolled sheet steels for automobile industries is needed in order to improve fuel efficiency by reducing vehicle weight. Dual-phase steel composed of ferritic-martensitic structure has received considerable attention from the automobile and steel industries because of its low yield ratio (yield stress/tensile strength) and good tensile strength-elongation relationships. ${ }^{1-3)}$ However, it has not been used successfully for wheel rim and disc fabrication, partly because of relatively low stretch-flangeability and low fatigue strength of this type of steel.

The authors have tried to develop a new type of steel which has better stretch-flangeability than dual phase steel, maintaining low yield ratio and good elongation, and have found that second phase bainite has a favorable effect on stretch-flangeability and fracture-toughness of deep drawn cups compared with martensite. ${ }^{4}$

High yield ratio and yield point elongation of ferrite-bainite steel are largely improved by introducing a small amount of martensite. The authors have proposed that ferrite-bainite-martensite or triphase steel whose volume fraction of bainite is higher than martensite, has nearly the best combination of mechanical properties as-cold-rolled steel sheets. ${ }^{4)}$

The present study is undertaken to clarify the effect of the nature of low temperature transformation products (LTTP) on the mechanical properties of multi-phase steels in the hot-rolled state.

\section{Experimental Procedures}

Laboratory steels used in this study were made into $90 \mathrm{~kg}$ vacuum-melted heats. The chmical compositions of the steels are shown in Table 1. These steel ingots were divided into 2 parts. One part was forged to $10 \mathrm{~mm}^{\phi}$ rods and were cold drawn to $7 \mathrm{~mm}^{\phi}$. These rods were intercritically heat treated in order to obtain various microstructures. The other part was hot rolled to $25 \mathrm{~mm}$ thick slabs and cut to 25 $\mathrm{mm}$ by $100 \mathrm{~mm}$ by $90 \mathrm{~mm}$ rolling blanks. The schematic representation in Fig. 1 provides details of laboratory simulation of hot strip mill processing of $4 \mathrm{~mm}$ 'gauge coiled sheets. After $1 \mathrm{hr}$ of heating at $1200{ }^{\circ} \mathrm{C}$, a $25 \mathrm{~mm}$ thick slab was descaled and rolled with a three-pass schedule to $4 \mathrm{~mm}$ gauge sheets. The sheets finish-rolled at $850^{\circ} \mathrm{C}$ were then controlled cooled to obtain different microstructures. Temperatures during hot rolling were monitored with an infrared pyrometer on the entry and delivery sides of the rolling mill. The cooling rates after finishrolling were changed by applying various cooling methods such as natural and accelerated air-cooling and mist cooling, in order to obtain various microstructures.

Microstructural examinations were made on a crosssection perpendicular to the drawing or rolling direction. The specimens were finally polished with buff, then etched in Lepera's etchant ${ }^{5}$ ) to distinguish bainite from martensite and examined by transmission electron microscopy. The optical micrographs were obtained at 400 magnification. The volume fraction of martensite and bainite was determined by the Quantimet image analysis. Microstructural constituents such as ferrite, bainite, martensite and pearlite are, hereinafter, expressed as $\mathrm{F}, \mathrm{B}, \mathrm{M}$ and $\mathrm{P}$, respectively,

Table 1. Chemical composition of steels. (wt \%)

\begin{tabular}{c|ccccccc}
\hline No. & C & Si & Mn & P & S & Cr & $\mathrm{Al}$ \\
\hline 1 & 0.05 & - & 1.24 & 0.044 & 0.005 & 0.94 & 0.029 \\
2 & 0.04 & 0.48 & 1.54 & 0.003 & 0.005 & 0.51 & 0.035 \\
3 & 0.05 & 0.52 & 1.51 & 0.003 & 0.008 & 0.96 & 0.020 \\
4 & 0.06 & 0.50 & 1.55 & 0.012 & 0.007 & 1.43 & 0.029 \\
5 & 0.10 & 0.50 & 1.59 & 0.003 & 0.005 & 0.96 & 0.020 \\
6 & 0.06 & 0.54 & 2.04 & 0.003 & 0.008 & 1.05 & 0.021 \\
7 & 0.06 & 0.98 & 1.52 & 0.003 & 0.008 & 1.03 & 0.015 \\
8 & 0.06 & 0.96 & 1.54 & 0.005 & 0.007 & 1.44 & 0.026 \\
\hline
\end{tabular}

* Originally published in Tetsu-to-Hagané, 68 (1982), No. 9, Special Issue on High Strength Sheet Steels, 1185, in Japanese; Formerly presented to the 101st ISIJ Meeting, April 1981, at The University of Tokyo in Tokyo. English version received July 2, 1982. (C) 1983 ISIJ

** Central Research Laboratory, Kobe Steel, Ltd., Wakinohama-cho, Chuo-ku, Kobe 651. 
and the microstructure is described as $\mathrm{F}+\mathrm{B}, \mathrm{B}+\mathrm{F}$, $\mathrm{F}+\mathrm{M}$ or $\mathrm{F}+\mathrm{B}+\mathrm{M}$. The micro-constituent with the higher or highest quantity in a microstructure is expressed first.

JIS 14A tensile specimens (50 $\mathrm{mm}$ gauge length and $3 \mathrm{~mm}$ in diameter for rods) and longitudinal ASTM type specimens (3 mm thickness, $12.5 \mathrm{~mm}$ in width and $50 \mathrm{~mm}$ gauge length for hot rolled sheets) were prepared. Tensile testing was conducted in an Instron machine with a cross head speed of $10 \mathrm{~mm} /$ min. Reduction of area obtained in JIS 14A specimen represents the ductility of specimens having no micro-cracks.

Hole expansion limit $\lambda$ for sheets was also measured to determine stretch-flangeability. $\lambda$ represents the ductility of specimens having micro-cracks produced by hole punching. Hot rolled sheets were ground to $3 \mathrm{~mm}$ and cut to $60 \mathrm{~mm}$ by $60 \mathrm{~mm}$ for the hole ex-

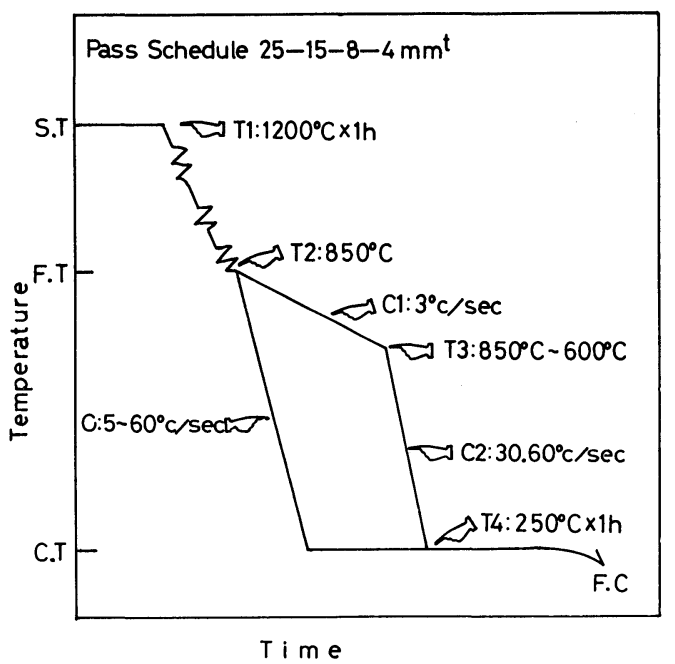

Fig. 1. Laboratory simulation of hot rolling and controlled cooling process. pansion test. The holes were made at the center of the sheets by punching. The punching clearance was $0.1 \mathrm{~mm}$ (punch diameter $10.0 \mathrm{~mm}$, die diameter 10.2 $\mathrm{mm}$ ). The hole expansion test was conducted by expanding a $10.0 \mathrm{~mm}$ punched hole using a conical punch with a top angle of $30 \mathrm{deg}$. The hole expansion limit $\lambda$ was expressed as the average stretch of the hole edge by the following equation:

$$
\lambda=\frac{d_{B}-d_{i}}{d_{i}}
$$

where, $d_{i}$ : initial diameter $(10 \mathrm{~mm})$

$d_{B}$ : fractured hole diameter.

The fractured hole diameter was determined when the crack developed fully in the sheet thickness.

\section{Results}

1. Effect of Micro-constituents on Tensile Properties and Stretch-flangeability of Multi-phase Steels

\section{Microstructure}

Photograph 1 shows the typical microstructures of No. 2 steels which were continuously cooled after hot rolling at cooling rates of 5,30 and $60{ }^{\circ} \mathrm{C} / \mathrm{s} . \quad 3 \%$ nithal etchant and Lepera's etchant were used. With Lepera's etchant, ferrite appears tan, bainite appears dark brown and martensite appears white. These observations correlate with the electron microscopy observations. At the cooling rate of $5{ }^{\circ} \mathrm{C} / \mathrm{s}, \mathrm{F}+\mathrm{M}$ structure, whose martensite content is small, was obtained. Bainite content increased with the increase in cooling rate after hot rolling, and $\mathrm{F}+\mathrm{B}+\mathrm{M}$ structure and $\mathrm{B}+\mathrm{M}$ structure samples were obtained at the cooling rate of 30 and $60^{\circ} \mathrm{C} / \mathrm{s}$, respectively. In this experiment, martensite (M) particles existed as particles surrounded by ferrite, martensite islands in bainitic ferrite, or martensite and bainite composites. Typical microstructures of $\mathrm{F}+\mathrm{M}$ and $\mathrm{F}+\mathrm{B}+\mathrm{M}$ structure steels are schematically illustrated in Fig. 2.

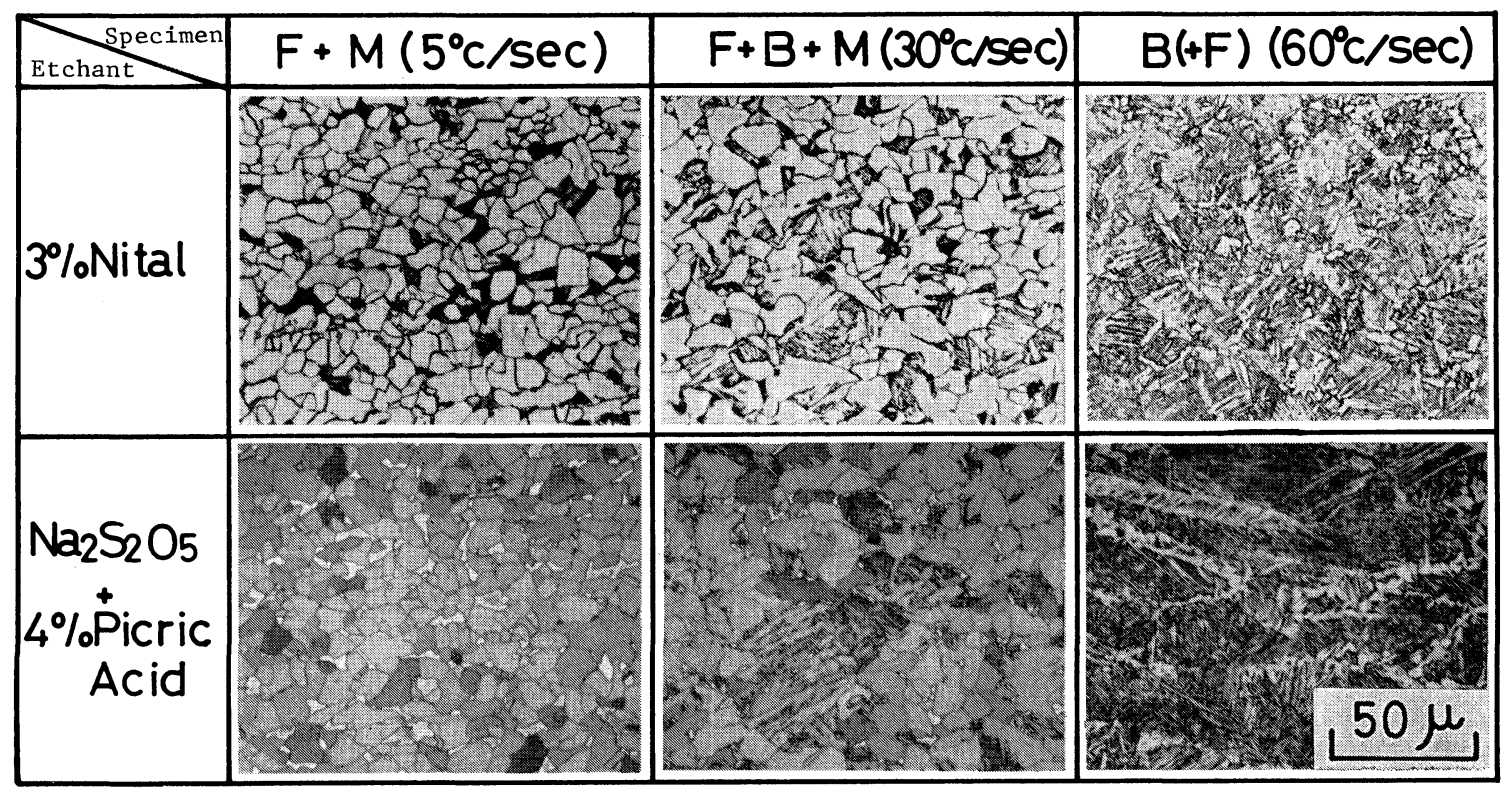

Photo. 1. Variations in microstructures of steel No. 2 as a function of cooling rate after hot rolling. 
Structure or state of B and $\mathrm{M}$ depends on unstable $\gamma$ grain size, degree of concentration of carbon and manganese to $\gamma$ grain, and cooling rate. During cooling, $\gamma$ grain size decreases and carbon enriches into $\gamma$ grain. So, carbon content in $r$ grain may increase, in general, as $\gamma$ grain size becomes smaller. This may explain the observations that the nature of LTTP changes from martensite to lower bainite and then to upper bainite as the LTTP particle sizes increase.

Photograph 2 shows typical transmission electron micrographs of LTTP particles composed of bainite and martensite. Photograph 2(a) shows a bright field micrograph of twinned martensite adjacent to bainite containing carbide, (b) shows a bright-field micrograph of martensites dispersed in bainite. Photograph 2(c) shows a dark-field micrograph of carbides in bainite in the center of Photos. 2(a) and (c) obtained by using carbide spots. This photograph also shows transformation twins in martensite at the upper side of bainite and the distance between them is a little wider than that of carbides in bainite. Photograph 2(d) is a dark-field micrograph of martensites in bainite as in Photo. 2(b). Martensites enclosed by ferrite grains were also examined by transmission electron microscopy. Although electron micrographs are not included in this paper, almost all the martensites

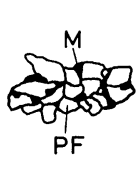

(a)

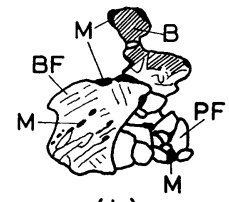

(b)
PF: Polygonal Ferrite

BF: Bainitic Ferrite

B: Bainite

M: Martensite

Fig. 2. Schematic illustration of typical microstructures of $\mathrm{F}+\mathrm{M}$ and $\mathrm{F}+\mathrm{B}+\mathrm{M}$ steels. are lath martensites when the martensite content is high. Sometimes twinned martensites were also found. They are formed from the austenite grains in which solute carbon is highly concentrated, so their particle sizes are, in general, small.

Retained austenite formed between ferrite laths of upper bainite were observed in some cases.

\section{Tensile Properties}

Figure 3 shows the relationships between tensile strength (TS) and yield ratio (YR) and reduction of area (RA) of $\mathrm{F}+\mathrm{M}, \mathrm{B}+\mathrm{F}$ and $\mathrm{F}+\mathrm{B}+\mathrm{M}$ structure steels. $\mathrm{F}+\mathrm{M}$ structure steel has lowest $\mathrm{YR}$ and lowest RA when compared at a same TS value. In contrast, $\mathrm{B}(+\mathrm{F})$ structure steel has highest $\mathrm{YR}$ and highest $\mathrm{RA}$. $\mathrm{F}+\mathrm{B}+\mathrm{M}$ structure steel has a value between the other two structure steels. In cold-rolled steel sheets, $\mathrm{F}+\mathrm{B}+\mathrm{M}$ structure steel has nearly the lowest YR and highest RA, that is to say, it has good shape-fixability and excellent stretch-flangeability. ${ }^{4)}$ So, the experiment was undertaken to improve the mechanical properties of the as-hot-rolled $\mathrm{F}+\mathrm{B}+\mathrm{M}$

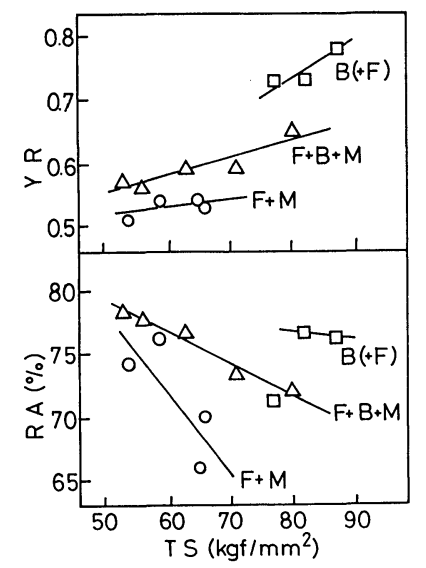

Fig. 3. Effects of microstructures on the mechanical properties of Nos. 2, 3, 4, 7 and 8 steels in the hot-rolled and controlled-cooled state.

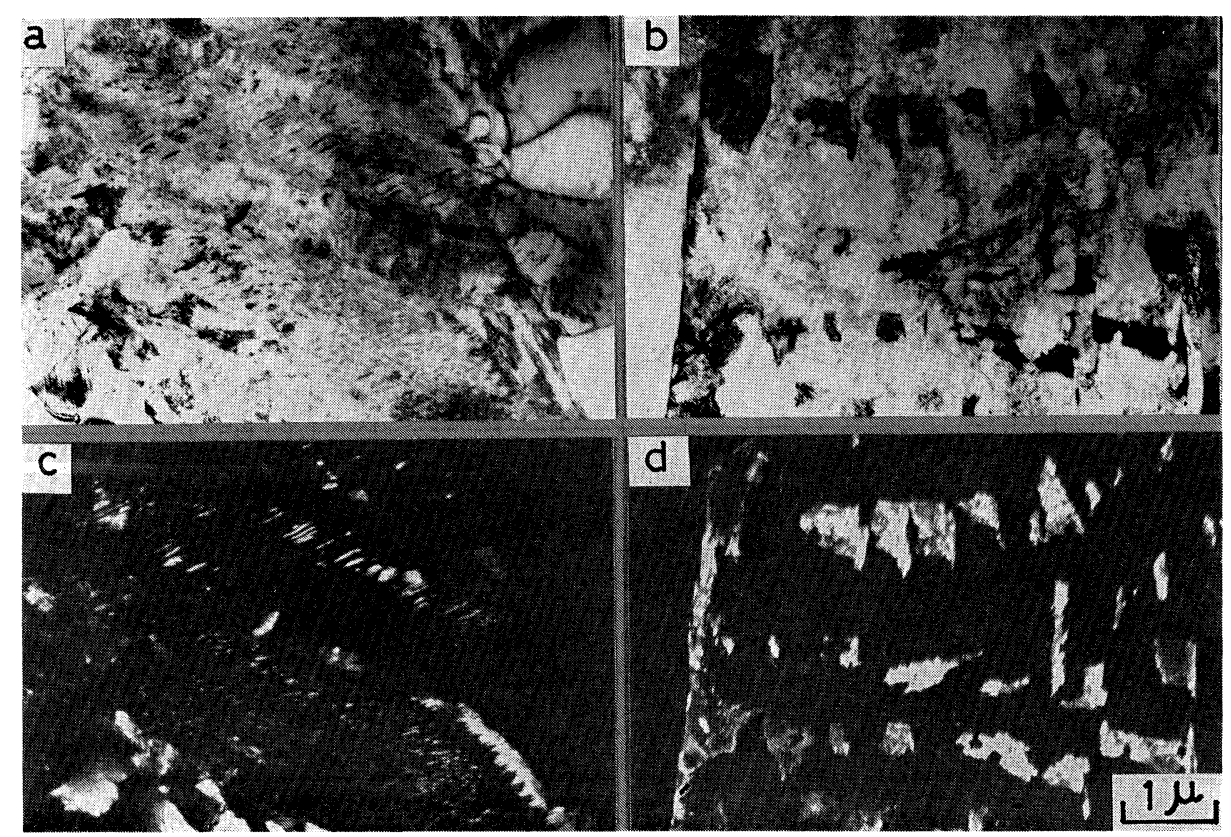

(a): A bright-field micrograph of bainite containing carbide and twinned martensite

(b): A bright-field micrograph of martensites dispersed in bainite

(c): A dark-field micrograph of carbides in bainite in Photo. 2(a) using precipitated spots

(d): A dark-field micrograph of martensite in Photo. 2(b)

Photo. 2. Transmission micrographs of steel No. 2 which were hot rolled and controlled cooled. 
structure steels.

\section{Effect of Bainite Content on the Mechanical Properties of $F+B+M$ Structure Steels}

\section{Microstructures}

Steel No. 3 was used in this experiment. Bainite content was changed by adapting various cooling patterns as shown in Fig. 1. Relationships between controlled-cooling conditions and micro-constituents are summarized in Table 2. The eight samples shown in Table 2 whose bainite content varied from 1 to $83 \%$ and martensite content ranged from 1 to $11 \%$ were investigated. Bainite content decreased in the order of Nos. 3A to $3 \mathrm{H}$. Martensite contents of Nos. $3 \mathrm{~B}$ to $3 \mathrm{~F}$ were nearly the same and that of Nos. $3 \mathrm{G}$ and $3 \mathrm{H}$ increased largely. Average ferrite grain sizes were nearly the same from the sample Nos. $3 \mathrm{D}$ through $3 \mathrm{H}$.

\section{Tensile Properties and Stretch-flangeability}

Figure 4 shows the effect of bainite content on the tensile properties of $\mathrm{F}+\mathrm{B}+\mathrm{M}$ structure steels. All the samples shown in Fig. 4 had no yield point elongation. The decrease in bainite content produced a decrease in YS, TS and YR, and increase in El. and $n$ value down to about $20 \%$ bainite. All teh properties remained nearly constant from 20 to $0 \%$ bainite content. In this region the martensite content ranges from 3 to $10 \%$ which is favorable content for dual-phase steel. These results indicate that the $\mathrm{F}+\mathrm{B}+\mathrm{M}$ steel which contains a small percent of martensite and less than $20 \%$ bainite has lowest YR value and highest $\mathrm{TS} \times \mathrm{El}$. value just as $\mathrm{F}+\mathrm{M}$ or dual-phase steel.

The YR of ferrite-bainite-martensite steel was lowered to the same value as dual-phase steel, but it must be taken into consideration that appropriately high YR is, in contrast, needed in some applications. From Fig. 4, appropriate YR can be obtained in triphase steel for practical demands by controlling bainite and martensite content.

Figure 5 shows the effect of bainite content on the hole expansion limit $(\lambda)$ and reduction of area (RA). $\lambda$ increases with the increase in bainite content and

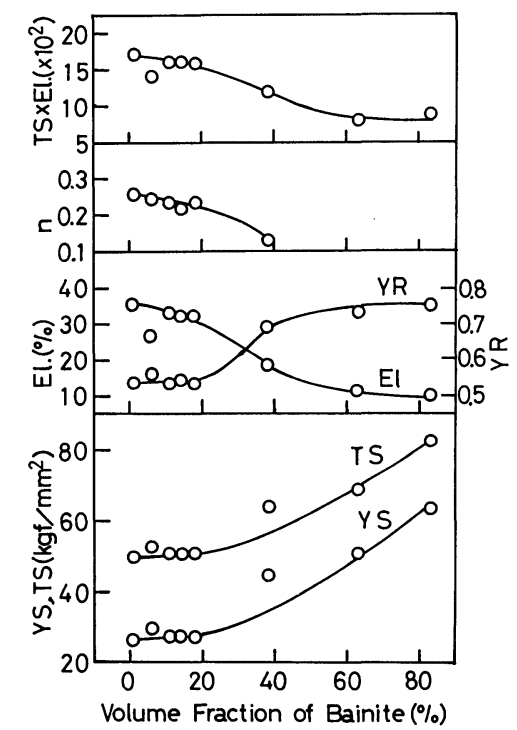

Fig. 4. Effects of bainite content on the mechanical properties of steel No. 3 which contains martensite content of 4 to $11 \%$.

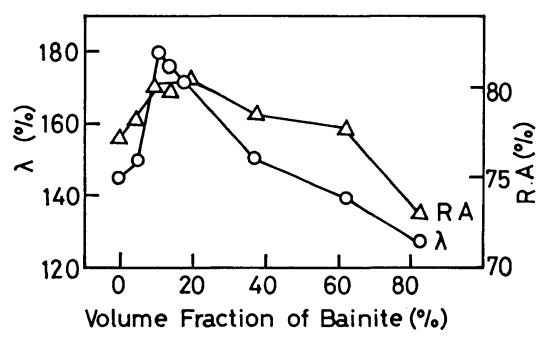

Fig. 5. Effect of bainite content on the hole expansion limit $(\lambda)$ and reduction of area (RA) of steel No. 3.

Table 2. Hot rolling conditions and microstructural analysis of steel No. 3 .

\begin{tabular}{|c|c|c|c|c|c|c|c|c|}
\hline \multirow{2}{*}{ No. } & \multirow{2}{*}{\multicolumn{2}{|c|}{ Hot rolling conditions }} & \multicolumn{3}{|c|}{ Volume fraction (\%) } & \multicolumn{3}{|c|}{ Vickers hardness (2 g) } \\
\hline & & & $\mathrm{F}$ & B & M & $\mathrm{F}$ & B & M \\
\hline $3 \mathrm{~A}$ & $T_{2}: 850 \longrightarrow 60^{\circ} \mathrm{C} / \mathrm{s} \longrightarrow T_{4}$ & C $\times 1$ h F.C & 16 & 83 & 1 & - & - & - \\
\hline $3 \mathrm{~B}$ & $T_{2}: 850 \stackrel{3{ }^{\circ} \mathrm{C} / \mathrm{s}}{\longrightarrow} T_{3}: 820^{\circ} \mathrm{G} \stackrel{60^{\circ} \mathrm{C} / \mathrm{s}}{\longrightarrow}$ & $"$ & 34 & 63 & 3 & 219 & 366 & - \\
\hline $3 \mathrm{G}$ & $T_{2}: 840 \longrightarrow 30^{\circ} \mathrm{C} / \mathrm{s}$ & $"$ & 59 & 38 & 3 & 184 & $339(238) *$ & 470 \\
\hline $3 \mathrm{D}$ & $T_{2}: 850 \stackrel{3{ }^{\circ} \mathrm{C} / \mathrm{s}}{\longrightarrow} T_{3}: 820^{\circ} \mathrm{G} \stackrel{30^{\circ} \mathrm{C} / \mathrm{s}}{\longrightarrow}$ & ” & 78 & 18 & 4 & - & - & - \\
\hline $3 \mathrm{E}$ & $T_{2}: 860 \longrightarrow$ & $"$ & 83 & 14 & 3 & - & - & - \\
\hline $3 \mathrm{~F}$ & $T_{2}: 850 \longrightarrow$ & $"$ & 85 & 11 & 5 & 161 & $358(226)^{*}$ & 470 \\
\hline $3 \mathrm{G}$ & $T_{2}: 850 \stackrel{3{ }^{\circ} \mathrm{C} / \mathrm{s}}{\longrightarrow} T_{3}: 700^{\circ} \mathrm{G} \stackrel{60^{\circ} \mathrm{C} / \mathrm{s}}{\longrightarrow}$ & $"$ & 85 & 6 & 9 & - & - & - \\
\hline $3 \mathrm{H}$ & $T_{2}: 850 \stackrel{3{ }^{\circ} \mathrm{C} / \mathrm{s}}{\longrightarrow} T_{3}: 600^{\circ} \mathrm{G} \stackrel{60^{\circ} \mathrm{C} / \mathrm{s}}{\longrightarrow}$ & $"$ & 88 & 1 & 11 & 150 & - & 490 \\
\hline
\end{tabular}

F : Polygonal ferrite, B : Bainite, M : Martensite

* Hardness of bainitic ferrite 
reaches its maximum at about $11 \%$ of bainite content and then rapidly decreases. RA reaches its maximum at bainite content of 10 to $20 \%$ and then gradually decreases up to $60 \%$ of bainite content, and then rapidly decreases. The reason why $\lambda$ decreases more rapidly than RA with the increase in bainite content may be a work-hardened surface formed in the edge region of a punched hole and micro cracks in the fractured surface. ${ }^{6}$ ) In both properties, $\lambda$ and RA, stretch-flangeability is good when bainite content ranges from 5 to $40 \%$ and especially good when bainite content is from 10 to $20 \%$. The results obtained on stretch-flangeability and tensile properties show that stretch-flangeability improves significantly with the increase in bainite content up to $20 \%$, even though TS remains nearly constant. It is shown that stretch-flangeability is improved by replacing $M$ with $B+M$ up to about $20 \%$ of LTTP content and that the tensile properties of the $\mathrm{F}+\mathrm{B}+\mathrm{M}$ structure steel are as good as $\mathrm{F}+\mathrm{M}$ structure steel.

A F +B structure steel was prepared and its mechanical properties were compared with those of $\mathrm{F}+$ $\mathrm{B}+\mathrm{M}$ and $\mathrm{F}+\mathrm{M}$ structure steels. Hot rolling conditions, microstructures and mechanical properties of typical $\mathrm{F}+\mathrm{M}, \mathrm{F}+\mathrm{B}+\mathrm{M}$ and $\mathrm{F}+\mathrm{B}$ steels are shown in Table 3. The three steels have nearly the same TS values. $\mathrm{F}+32 \% \mathrm{~B}$ steel has yield point elongation, high YR and low TS $\times$ El. values. It is confirmed that $\mathrm{F}+\mathrm{B}+\mathrm{M}$ structure steel composed of appropriate structure (e.g., ferrite plus $11 \%$ bainite plus $5 \%$ martensite) has a high $\lambda$ value as $\mathrm{F}+\mathrm{B}$ steel, and a high TS $\times$ El. value and low YR just as $\mathrm{F}+\mathrm{M}$ steel. Therefore, it has the best combination of mechanical properties as far as this experiment is concerned.

\section{Discussion}

The results mentioned above show that triphase steels composed of appropriate structure have better mechanical properties than $\mathrm{F}+\mathrm{M}$ structure (dualphase) steels. The advantage of this structure steel is better stretch-flangeability than $\mathrm{F}+\mathrm{M}$ steel and also a better fatigue strength and toughness which are not mentioned in this paper. So, the deformation behavior and ductile fracture of $\mathrm{F}+\mathrm{B}+\mathrm{M}$ and $\mathrm{F}+\mathrm{M}$ structure steels will be examined first and then how the stretch-flangeability of triphase steels is improved will be discussed.

\section{Deformation Behavior of $F+B+M$ Structure Steels}

The deformation behavior of typical samples Nos. $3 \mathrm{~B}, 3 \mathrm{C}, 3 \mathrm{~F}$ and $3 \mathrm{H}$ were examined. As shown in Table 2, bainite and martensite contents differ from each other. Work hardening rate $(d \sigma / d \varepsilon)$ and $n$ value were obtained as follows. True stress and true strain regression formula was deduced from the results by assuming

$$
\ln \sigma=a_{0}+a_{1} \ln \varepsilon+\ldots+a_{6}(\ln \varepsilon)^{6}
$$

A comparison of observed and calculated true stress and strain showed excellent agreement. According to this equation, $d \sigma / d \varepsilon$ and $\mathrm{n}(d(\ln \sigma) / d(\ln \varepsilon))$ values were calculated, where $n$ and $K$ values were assumed to satisfy a function of strain $\varepsilon, \sigma=K \cdot \varepsilon^{n}$.

Figure 6 shows the comparison of observed data and calculated stress-strain curve for the four samples. The empirical equation fits the observed data very well. The stress decreases with the decrease in bainite content and the true stress-true strain curves of the $\mathrm{F}+\mathrm{M}(\mathrm{No} .3 \mathrm{H}$ ) and of $\mathrm{F}+\mathrm{B}+\mathrm{M}$ (No. 3F) samples are nearly the same. The relationships between true strain and work hardening rate and $n$ value shown in Fig. 7. Work hardening rate decreases rapidly in small strain range, then decreases gradually. Work hardening rate also depends on bainite content and decreases more rapidly as the bainite content decreases. However, $\mathrm{F}+11 \% \mathrm{~B}+5 \% \mathrm{M}$ sample and $\mathrm{F}+11 \% \mathrm{M}+1 \% \mathrm{~B}$ sample have nearly the same

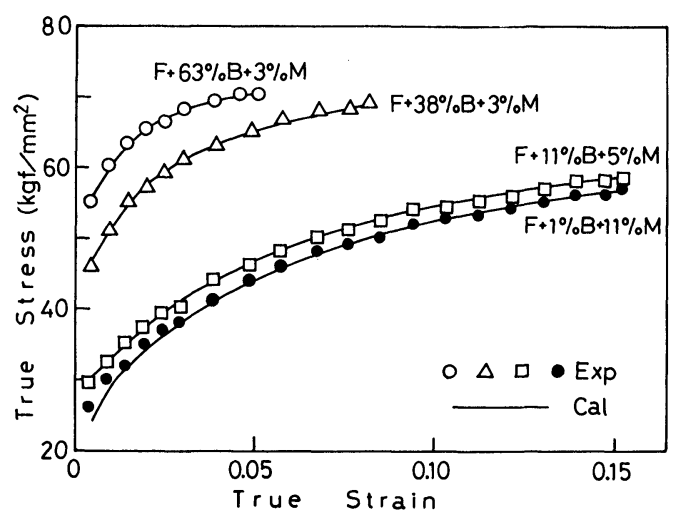

Fig. 6. Effect of microstructures on the true stress-strain curves for steel No. 3. Comparisons between the experimental data and the prediction based on Eq. (2) are also shown.

Table 3. Microstructures and mechanical properties of Steel No. 3.

\begin{tabular}{|c|c|c|c|c|c|c|c|c|c|c|c|}
\hline \multirow{2}{*}{ No. } & \multirow[b]{2}{*}{ Hot rolling conditions } & \multicolumn{3}{|c|}{$\begin{array}{c}\text { Volume } \\
\text { fraction (\%) }\end{array}$} & \multicolumn{7}{|c|}{ Mechanical properties } \\
\hline & & $\mathrm{F}$ & B & $\mathbf{M}$ & $\begin{array}{c}\text { YS } \\
(\mathbf{k g f} / \\
\left.\mathrm{mm}^{2}\right)\end{array}$ & $\begin{array}{c}\mathrm{TS} \\
(\mathbf{k g f} / \\
\left.\mathrm{mm}^{2}\right)\end{array}$ & $\begin{array}{l}\text { El. } \\
(\%)\end{array}$ & $\begin{array}{l}\text { YPE } \\
(\%)\end{array}$ & YR & $\begin{array}{c}\text { TS } \times \\
\text { El. }\end{array}$ & $\begin{array}{c}\lambda \\
(\%)\end{array}$ \\
\hline $3 \mathrm{H}$ & $T_{2}: 850^{\circ} \mathrm{C} \stackrel{3^{\circ} \mathrm{C} / \mathrm{s}}{\longrightarrow} T_{3}: 600^{\circ} \mathrm{C} \stackrel{60^{\circ} \mathrm{C} / \mathrm{s}}{\longrightarrow} T_{4}: 250^{\circ} \mathrm{C} \times 1 \mathrm{~h}$ & 88 & 1 & 11 & 25.9 & 49.2 & 33.2 & 0 & 0.526 & 1688 & 146 \\
\hline $3 \mathrm{~F}$ & $5^{\circ} \mathrm{C} / \mathrm{s}$ & 85 & 11 & 5 & 26.9 & 50.4 & 32.7 & 0 & 0.533 & 1648 & 179 \\
\hline $3 Q$ & $T_{2}: 850^{\circ} \mathrm{C} \stackrel{20^{\circ} \mathrm{C} / \mathrm{s}}{\longrightarrow} T_{3}: 600^{\circ} \mathrm{C} \stackrel{60^{\circ} \mathrm{C} / \mathrm{s}}{\longrightarrow} T_{4}: 450^{\circ} \mathrm{C} \times 1 \mathrm{~h}$ & 68 & 32 & 一 & 36.1 & 48.8 & 24.7 & 1.1 & 0.739 & 1206 & 162 \\
\hline
\end{tabular}


relationship between work hardening rate and strain. $n$ value increases in small strain range, reaches maximum value $\left(n_{0}\right)$ and then decreases gradually. The maximum $n$ value and strain $\varepsilon_{0}$ where $n_{0}$ is obtained, decrease with the increase in bainite content. The small strain range up to $\varepsilon_{0}$ corresponds to the region where only ferrite grains are deformed. The $\mathrm{F}+$ $11 \% \mathrm{M}+1 \% \mathrm{~B}$ sample and $\mathrm{F}+11 \% \mathrm{~B}+5 \% \mathrm{M}$ sample have nearly the same relationship between $n$ value and strain, but the difference between $n$ values of two structure samples is prominent in small strain range up to $\varepsilon_{0}$ and then diminishes gradually.

The reason why $n$ value of $\mathrm{F}+\mathrm{M}$ structure steel is the highest in the strain range where only ferrite phase deforms may be as follows:

(1) High $n$ value due to purified ferrite grain ${ }^{8)}$

(2) High $n$ value due to martensitic transformation of retained $\gamma^{9)}$

(3) High $n$ value due to disappearance of yield point elongation

(4) High $n$ value due to ferrite grain size

Retained austenite content (2) for $F+M$ steel and

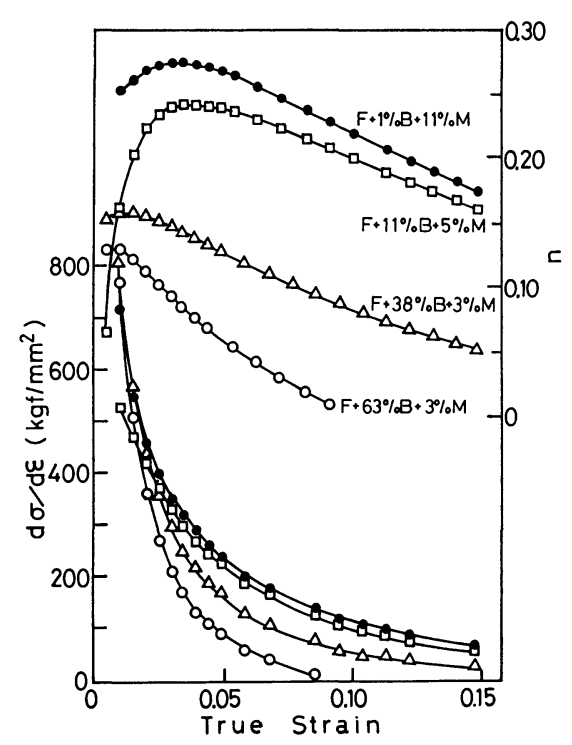

Fig. 7. Effect of microstructures on the relationships between true strain and work hardening rate $(d \sigma / d \varepsilon)$ and $n$ value $(d(\ln \sigma) / d(\ln \varepsilon))$ for steel No. 3 .
$\mathrm{F}+\mathrm{B}+\mathrm{M}$ steel were determined by $\mathrm{X}$-ray measurement and was about $1.1 \%$ for both steels. Yield point elongation (3) was not observed in both steels. Ferrite grain size (4) for both structure steels was the same. Therefore, the remaining factor (1) will be a possible cause of high $n$ value of the $\mathrm{F}+\mathrm{M}$ structure sample. It was already found by internal friction measurement that during slow cooling from $\gamma$ region, solute carbon in ferrite diffuses into $\gamma$ grains to stabilize $\gamma$ phase and purify ferrite grains. ${ }^{4)}$ Although solute carbon content was not measured in this experiment, solute carbon content of the $\mathrm{F}+\mathrm{B}+\mathrm{M}$ sample may be higher than that of the $\mathrm{F}+\mathrm{M}$ sample, considering that ferrite hardness and cooling rate in the temperature ranging from 850 to $600{ }^{\circ} \mathrm{G}$ of the $\mathrm{F}+\mathrm{B}+\mathrm{M}$ structure steel are higher than those of the $F+M$ structure steel as shown in Table 2. This may partially explain the higher $n$ value of $\mathrm{F}+\mathrm{M}$ steel compared with $\mathrm{F}+\mathrm{B}+\mathrm{M}$ structure steel.

\section{Stretch-flangeability of $F+B+M$ Structure Steels}

Ductile fracture phenomena in $\mathrm{F}+\mathrm{B}+\mathrm{M}$ and $\mathrm{F}+\mathrm{M}$ steels were compared during tensile testing in order to know why the stretch-flangeability of $\mathrm{F}+$ $\mathrm{B}+\mathrm{M}$ steel is better than of $\mathrm{F}+\mathrm{M}$ steel. A $5 \mathrm{~mm}$ in diameter steel rod made from steel No. 3 was cut into $170 \mathrm{~mm}$ in length rods which were used to examine the ductile fracture process quantitatively. Heat treatment was applied to the rods to get the desired microstructure and the microstructure obtained are shown in Table 4 . The tensile properties of the steels are summarized in Table 5. The microstructure of both samples were just the same as for the No. $3 \mathrm{~F}$ and $3 \mathrm{H}$ samples in the previous section. Ferrite grain size and martensite particle size of sample No. 3J are little larger than of sample No. 3I. Table 5 shows that YR and TS $\times$ El. values are the same for both samples and that $n$ value in No. 3J and RA value in No. 3I are higher than the other. These results are in good agreement with the results mentioned above.

The ductile fracture process of both structure samples was examined using tensile fractured specimens. To determine the strain precisely at each point from the fractured surface, the fractured specimens were

Table 4. Heat treatment and microstructural analysis of samples No. 3.

\begin{tabular}{c|c|crrrr}
\hline No. & Heat treatment & $\begin{array}{c}\text { Ferrite } \\
(\%)\end{array}$ & $\begin{array}{c}\text { Bainite } \\
(\%)\end{array}$ & $\begin{array}{c}\text { Martensite } \\
(\%)\end{array}$ & $\begin{array}{c}\text { F.G.S* } \\
(\mu)\end{array}$ & $\begin{array}{c}\text { M.P.S** } \\
(\mu)\end{array}$ \\
\hline $3 \mathrm{I}$ & $900^{\circ} \mathrm{C} \times 10 \mathrm{~min} \stackrel{\mathrm{A} . \mathrm{G}}{\longrightarrow} 400^{\circ} \mathrm{C} \times 10 \mathrm{~min} \mathrm{A.C}$ & 79 & 14 & 7 & 12.4 & 2.8 \\
\hline $3 \mathrm{~J}$ & $900^{\circ} \mathrm{C} \times 10 \mathrm{~min} \longrightarrow 700^{\circ} \mathrm{C} \times 10 \mathrm{~min} \mathrm{A.C}$ & 87 & - & 13 & 15.6 & 5.8 \\
\hline
\end{tabular}

* Ferrite grain size, ** Martensite particle size

Table 5. Mechanical properties of samples No. $3 \mathrm{I}$ and $3 \mathrm{~J}$.

\begin{tabular}{c|cccccccc}
\hline No. & $\begin{array}{c}\text { YS } \\
\left(\mathrm{kgf} / \mathrm{mm}^{2}\right)\end{array}$ & $\begin{array}{c}\mathrm{TS} \\
\left(\mathrm{kg} / \mathrm{f} / \mathrm{mm}^{2}\right)\end{array}$ & $\begin{array}{c}\text { El. } \\
(\%)\end{array}$ & $\begin{array}{c}\text { YPE } \\
(\%)\end{array}$ & YR & TS $\times$ El. & $n$ & $\begin{array}{c}\text { RA } \\
(\%)\end{array}$ \\
\hline 3 I & 24.3 & 54.7 & 34.1 & 0 & 0.445 & 1864 & 0.222 & 68.9 \\
3J & 24.4 & 55.2 & 33.1 & 0 & 0.442 & 1826 & 0.239 & 61.0 \\
\hline
\end{tabular}


photographed at the magnification of 20, using a profile projector. The true strain $\varepsilon_{X}$, at a point $X \mathrm{~mm}$ apart from the fractured surface, was calculated according to the following equation:

$$
\varepsilon_{X}=\ln \left(D_{0} / D_{X}\right)^{2}
$$

where, $D_{0}$ : initial diameter of the specimen

$D_{X}$ : diameter at $X \mathrm{~mm}$ apart from the fractured surface.

The relationship between $\varepsilon_{X}$ and distance $X$ is shown in Fig. 8. The maximum strain or strain at fractured surface is larger in the $F+B+M$ sample than in the $\mathrm{F}+\mathrm{M}$ sample. The difference between the $\varepsilon_{X}$ values in both samples decreases with the increase in distance $X$ from fractured surface and becomes nearly the same beyond $3.0 \mathrm{~mm}$. These results agree with

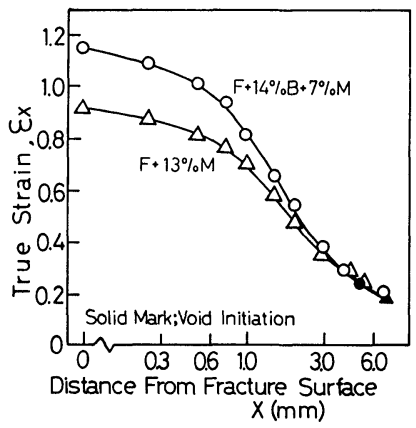

Fig. 8. Effect of microstructures on the relationship between true strain $\varepsilon_{X}$ and distance from fractured surface for steel No. 3 . the fact that $\mathrm{RA}$ of $\mathrm{F}+\mathrm{B}+\mathrm{M}$ sample is higher than that of the $F+M$ sample.

The void initiation and deformation of ferrite and hard phase with the increase in $\varepsilon_{X}$ were observed using SEM (Scanning Electron Microscopy). The strains of void initiation were 0.25 and 0.20 for the $\mathrm{F}+\mathrm{B}+\mathrm{M}$ sample and $\mathrm{F}+\mathrm{M}$ sample, respectively. The typical examples of void formation are shown in Photo. 3. The density of voids is much higher in the $\mathrm{F}+\mathrm{M}$ sample than in the $\mathrm{F}+\mathrm{B}+\mathrm{M}$ sample. Larger voids are formed by the splitting of ferrite-martensite interfaces and by cracking of martensite particles in $\mathrm{F}+\mathrm{M}$ samples. In $\mathrm{F}+\mathrm{B}+\mathrm{M}$ samples, voids are mainly formed by the splitting of ferrite-LTTP interfaces and not by cracking of martensite particles. Photograph 4 shows the scanning electron micrographs of fractured surfaces of samples No. 3I and 3J. Cleavage fractured surfaces which may have been caused by cracking of martensite particles, were observed in $\mathrm{F}+\mathrm{M}$ samples but not in $\mathrm{F}+\mathrm{B}+\mathrm{M}$ samples.

These differences in ductile fracture between two structure samples can be explained, mainly, by the difference in deformability of bainite and martensite. Most of the bainite obtained in this experiment is identified as type I bainite and much softer than martensite or other type II, III bainite as shown in Table 2. So, bainite can deform as easily as ferrite matrix and voids are formed less frequently than in $F+M$ samples. In contrast, martensite is too hard to deform as ferrite matrix does and cracking of martensite

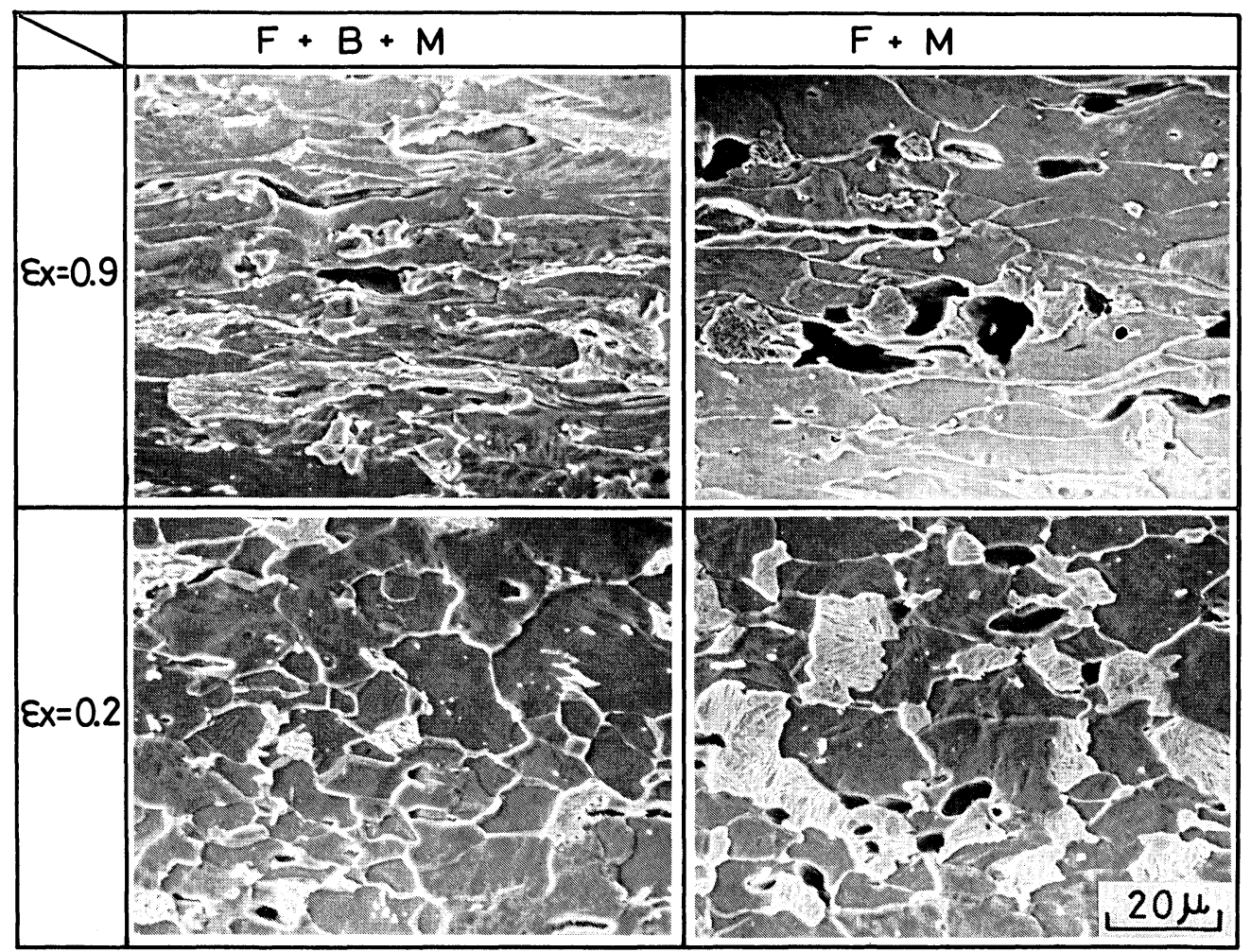

Photo. 3. Scanning electron micrographs of steel No. 3 showing the void formation.

The density of voids is much higher in ferrite-martensite steel than in ferrite-bainite-martensite steel. Voids are formed mainly due to the splitting of the ferrite-martensite (and bainite) boundaries and partially due to the cracking of martensite particles. 


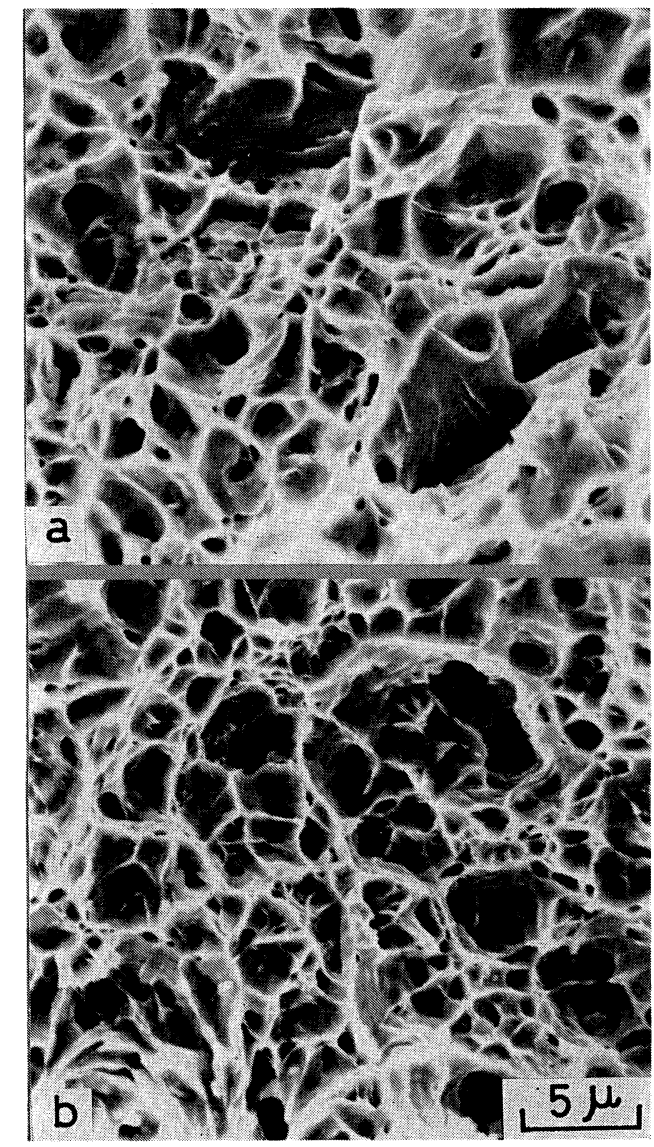

(a): Ferrite-martensite steel shows a mixed type of surface which is composed of dimpled and of cleavage fractured surface

(b): Ferrite-bainite-martensite steel shows a heavily dimpled surface

Photo. 4. Scanning electron micrographs of steel No. 3.

and splitting of ferrite-martensite interface occur. The next point to be elucidated is why cleavage fracture due to cracking of martensite was observed only in the $\mathrm{F}+\mathrm{M}$ sample, even though both structure steels contained martensite particles. The difference in martensite content is not large enough to explain the differences in the density of cleavage fractured surfaces and in the density of voids.

The effects of size and distribution of martensite were, then, examined. The martensite particle areas were measured, and the particle sizes were calculated assuming that the shape of the particles observed in micrographs is circular. The calculated diameter of the particles does not represent the absolute value of the assumed particle sphere, but represents only the diameter of the particle intersected by a random cross section or a polished cross section. However, these calculated particle diameters should be correlated with the absolute particle diameters. The distribution of the calculated diameters of both samples is shown in Fig. 9. Almost all the martensite particles of the $\mathrm{F}+\mathrm{B}+\mathrm{M}$ sample are smaller than 6.6 $\mu \mathrm{m}$, but the $\mathrm{F}+\mathrm{M}$ sample contains martensite particles larger than $6.6 \mu$ in diameter.

It is well known that a large hard phase may provoke ductile fractures. In this experiment it was

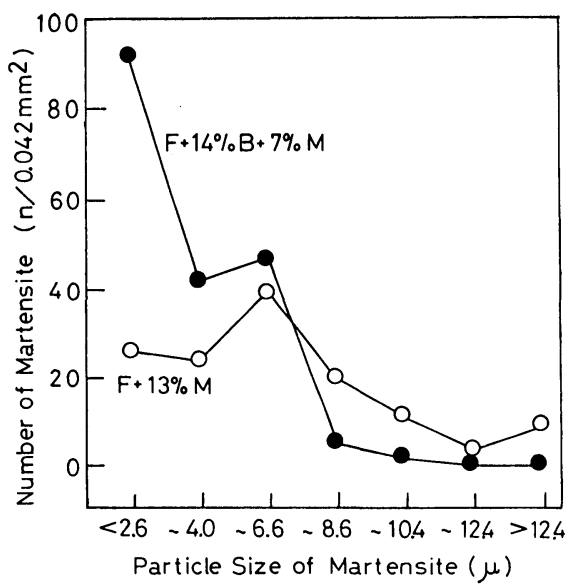

Fig. 9. Particle size distribution of martensite in $\mathrm{F}+$ $14 \% \mathrm{~B}+7 \% \mathrm{M}$ and $\mathrm{F}+13 \% \mathrm{M}$ samples for steel No. 3.

thought that a smaller amount and smaller size of martensite in $\mathrm{F}+\mathrm{B}+\mathrm{M}$ steel will improve the strain to ductile fracture. If this is true, the reduction of area (RA) of the $\mathrm{F}+\mathrm{B}+\mathrm{M}$ sample which is produced by introducing a small amount of martensite to $\mathrm{F}+\mathrm{B}$ steel reaches its maximum at bainite content of 10 to $20 \%$, and this may be explained as follows. Frequency of void initiation due to splitting of ferritemartensite interface and cracking of martensite is decreased, first, by replacing large amounts of martensite with softer bainite and second, by making smaller martensite particles. Therefore, reduction of area (RA) and hole expansion limit ( $\lambda$ ) are improved. Introduction of more than $20 \%$ bainite content increases tensile strength and deteriorates $\lambda$.

\section{Conclusion}

The effects of the amount of martensite and bainite on the mechanical properties of low carbon steel sheets have been examined. The results obtained are summarized as follows:

(1) Decreasing bainite content in F+B steel and introducing a small amount of martensite improve total elongation and $n$ value while they decrease yield ratio as in $\mathrm{F}+\mathrm{M}$ steel. High $n$ value in small strain region is mainly due to the purification of the ferrite grains.

(2) Reduction of area and hole expansion limit ( $\lambda$ ) are also better in $\mathrm{F}+\mathrm{B}+\mathrm{M}$ steel than in $\mathrm{F}+\mathrm{M}$ steel. Deformability of $\mathrm{F}+\mathrm{B}+\mathrm{M}$ (triphase) steel is improved by reduction of void formation due to splitting of ferrite-bainite interface and due to the smaller size of martensite, although voids can be easily initiated at ferrite-martensite interface in the $\mathrm{F}+\mathrm{M}$ steels.

(3) In this experiment the best combinations of shape fixability (low yield ratio), stretchability (high $n$ value) and stretch-flangeability were obtained in triphase steel sheets which were composed of $\mathrm{F}+10 \sim$ $20 \% \mathrm{~B}+3 \sim 5 \% \mathrm{M}$ microstructure.

\section{Acknowledgements}

The authors are grateful to Mr. Nobuo Kondo of 
Central Research Lab. of Kobe Steel, Ltd., for SEM and Transmission Electron Microscopy observations, and to Mr. Hiromi Hori of Central Research Lab. of Kobe Steel, Ltd., for his technical assistance.

\section{REFERENCES}

1) S. Hayami and T. Furukawa: Proceedings of Micro Alloying 75, Union Carbide Corp., New York, (1977), 78.

2) T. Matsuoka and K. Yamamori: Met. Trans., 6A (1975), 1613.

3) M.S. Rashid: SAE Papers 760206 (1976) and 770211
(1977).

4) M. Sudo, M. Higashi, H. Hori, T. Iwai, S. Kambe and Z. Shibata: Trans. ISIJ, 21 (1981), 820.

5) F. S. Lepera: J. Metals, 32 (1980), No. 3, 38.

6) K. Hosono, I. Nakagawa and K. Yoshida: J. Japan Soc. Tech. Plasticity, 9 (1968-9), 637.

7) M. Sudo, S. Hashimoto and S. Kambe: Tetsu-to-Hagané, 68 (1982), 1211; Trans. ISIJ, 23 (1983), 303.

8) R. G. Davies: Met. Trans., 9A (1978), 41.

9) J. M. Rigsbee and P.J.V. Arend: Proceedings of Formable HSLA and Dual-phase steels, ed. by A. T. Davenport, AIME, New York, (1979), 167. 